\title{
Development Media Interactive Learning in Education Pancasila and Citizenship Education to Improve Tolerance of Students in Elementary School
}

\author{
Vina Iasha, Mohamad Syarif Sumantri, Sarkadi Sarkadi, Reza Rachmadtullah \\ Universitas Negeri Jakarta \\ Jakarta, Indonesia \\ humas@unj.ac.id
}

\begin{abstract}
This study aims to develop interactive learning media on learning Pancasila and Citizenship Education in Elementary School. This study uses the Research and Development. Procedure studies using models dick and carey which has ten stages, namely: (1) Analysis of needs and learning goals; (2) analysis of learning; (3) analyzing the learner and the environment; (4) formulate the performance objectives; (5) develop instruments; (6) develop learning strategies; (7) the development and selection of learning materials; (8) implement formative evaluation; (9) revising learning; (10) designing and implementing a summative evaluation. The instrument in this research using a questionnaire to determine the feasibility of the media in terms of expert validation and field testing and subsequent use test instrument for measuring the tolerance of students. The evaluation was done in three stages, the first stage of expert judgment the do by media experts and material Pancasila and Citizenship. Step conducted an evaluation of a small group of ten students. The test results stated that interactive learning media fit for use. To see the effectiveness of the products developed followed by latest field group with 30 students. Result-test analysis showed differences in learning outcomes between pre-test and post-test. Judging from the average value, indicating that the media developed effectively used in improving tolerance and Students in Learning Pancasila Pancasila and Citizenship Education in Elementary School.
\end{abstract}

Keywords - learning media interactive; pancasila and citizenship education; tolerance

\section{INTRODUCTION}

Therefore, teachers should be able to innovate and be creative in order to design an attractive and meaningful learning for students. Mohamad Sumantri [1] in The observations suggested learning media can be selected with the consideration will provide support to the content of learning materials and the ease of acquiring it, but if media appropriate learning is not available, then the teacher should strive to develop it themselves, the development of instructional media can simply be developed by teachers themselves. In addition to using appropriate learning methods, teachers should also be able to use media that utilize computer media as a means to show the concepts of Pancasila and Citizenship Education abstract becomes visible concrete. Teachers can utilize program the Adobe Flash to create mind maps that can connect concepts and material so that the use of instructional interactive media makes the students interested and motivated to learn Pancasila and citizenship education (PPKn)

But in fact, the media as a source of learning and has been known as a tool in the learning process should be utilized teachers are often overlooked. Not exploited the media in the learning process is generally caused by various reasons such as preparation time is limited, difficult to find the right media, and other costs are not available [2].

Based on field observations and interviews conducted by the researchers of the teacher, it is known that the limited media that is used during the process of learning activities Pancasila and citizenship education. In Indonesia has ethnic and cultural diversity because Indonesia is an archipelagic country. The first reason is that Indonesia consists of a diverse population with many different ethnic and religious backgrounds [3]. There are perhaps 600 different ethnicities from Sabang to Merauke. In addition to this, Indonesia is also a diverse nation in terms of religion. For example, law number 1 / PNPS / 1965 stated that Indonesia has six religions, the which are Islamic, Christian, Buddhism, Hinduism, and Confucianism Protestant. However, although this country consists of six religions, Muslim people are the Reviews largest population. Thus, teaching tolerance is needed in schools.

According to this problem by developing an interactive learning media can play a role in the learning process Pancasila and Citizenship Education is certainly changing times and has its own appeal to learn so that students can construct their understanding through the media developed.

Learning to use interactive learning media is important to research results Arshi Gouhar [4] in his study suggests that the use of technology in education to facilitate effective and efficient learning and also for the achievement of learning goals. In line with the above expert opinion, Wanda in his research on the learner class I Elementary School stated that with their multimedia interactive learning and students will be more easily and quickly understand the subject matter, other than that the learning process will be more interesting.

Punctuated by the Adi Prawiro Sasmito opinion, and Andjrah Hamzah Irawan in interactive learning media research 
as one of learning media supporting the teaching and learning process in schools for fifth grade elementary easily understood materially and easier for students to see the real thing or object. Provide more value to help educators in providing science education that is interesting, fun and easy to understand to improve the student achievement grade elementary school.

Based on the results of problem identification and study of the relevant theory above, it was decided that in this study, the researchers conducted the development of interactive learning media on Pancasila and citizenship education learning in primary school. Developed an interactive learning media is a combination of text, images, animations using adobe flash player application, which is packaged in the form of an interactive $\mathrm{CD}$ so that students are able to operate on the computer.

Further learning is done using interactive learning media centered on learners so that learning becomes active and interactive, learners feel younger to understand the learning materials so that the use of instructional learning using interactive learning media can improve learners learn hail. This is in line with the results of research Elmagzoub mentioned that developing multimedia applications can contribute to solve some problems in education, if the government really want to take advantage of multimedia applications as an effective tool to improve learning.

The use of interactive learning media has a positive impact in the learning process can increase the motivation, selfconfidence so that it can help increase the interest and learning achievement of learners this is in accordance with the opinion of Aloraini in his research suggests Multimedia has a positive impact on cognitive achievement, academic achievement, comprehension and application. Can be interpreted learning using multimedia has a positive impact on cognitive achievement, academic achievement

\section{METHOD}

The method in this study using research and development. This research is manufacture interactive media interactive learning using Adobe Flash Player on Pancasila and Citizenship Education learning. The procedures used in this research, using research procedures and models using the model dick carey which has ten stages, namely: (1) Analysis of needs and learning goals; (2) analysis of learning; (3) analyzing the learner and the environment; (4) formulate the performance objectives; (5) develop instruments; (6) develop learning strategies; (7) the development and selection of learning materials; (8) implement formative evaluation; (9) revising learning; (10) designing and implementing a summative evaluation.

The subjects were students of class V Elementary School Harapan Jaya V Kota Bekasi Indonesia amounted to 30 respondents where the pilot phase Small Group Try-Out 10 respondents, at the stage of trial Field Try-outs 30 respondents.

The data used are quantitative and qualitative data. The qualitative data obtained from analysis of requirements, test questionnaire materials experts, test design experts. Meanwhile, quantitative data obtained from the test results of products, ie field test. The study design used was one group pretest-posttest design [5]. In this design, prior to the treatment given first students were given pre-test and the end of the lesson the students were given a posttest. This design is used to determine the effectiveness of the products made.

\section{RESULT AND DISCUSSION}

The products are successfully developed in this study is an interactive learning media on learning Pancasila and Citizenship in primary school, media designed using adobe flash player application, which is packaged in a CD, so that students can operate on your computer into a media self. Before designing learning stages interactive, researcher perform a needs analysis to find appropriate learning media information to be developed, after the results of a needs analysis obtained by the researchers drafting the manufacture of products designed according to the material that has been formulated. The material collected comes from sources that have been tested so interactive learning media prepared in make and developed.

After media interactive learning developed later, followed by validation by a person skilled Pancasila and Citizenship Education material and one media expert validation learning performed to obtain an assessment of interactive learning media. The assessment results of the validation by subject matter experts can be seen in the table 1 .

TABLE I. RESULTS OF ASSESSMENT BY EXPERTS MATERIAL

\begin{tabular}{|l|l|}
\hline \multicolumn{1}{|c|}{ Aspects } & \multicolumn{1}{c|}{ Average } \\
\hline Feasibility Content & 3.75 \\
\hline Content Development & 4.00 \\
\hline The final score & 3.875 \\
\hline
\end{tabular}

Results of judging by expert Pancasila and Citizenship Education feasibility aspect has an average content of 3.75 with the criteria of "very good", for aspect development of materials with valuable ratings of 4.00 with the criteria of "very good". So the final score worthiness worth 3,875 interactive learning media can be said that the development of interactive learning media on the subjects of Pancasila and Citizenship Education worthy of an expert assessment of the material. Furthermore, the media expert validation results can be seen from the table.

TABLE II. RESULTS OF EXPERT ASSESSMENT OF LEARNING MEDIA

\begin{tabular}{|l|l|}
\hline \multicolumn{1}{|c|}{ Aspects } & Average \\
\hline Eligibility Contents & 3.80 \\
\hline Accuracy Matter & 3.70 \\
\hline Display Ratings & 4.00 \\
\hline Language Assessment and Readability & 3.85 \\
\hline Total & 3,83 \\
\hline
\end{tabular}

Media expert validation results show the feasibility aspect of the contents of obtaining an average value of 3.80 aspects of the material accuracy of an average gain of 3.70, aspect display ratings average value of 4.00 , aspects of language assessment and legibility scored 3.85 , So the final score of the feasibility of interactive learning media worth 3.83 can even say that the 
development of interactive learning media on the subjects of Pancasila and Citizenship Education worthy of an expert assessment of learning media

In the media after validation by subject matter experts and then do the media expert trial Try- Small Group a ten-man out involving elementary school fifth grade students. The trial results from Small Group Try-Out can seen in the table:

TABLE III. TRIAL TRY-OUT SMALL GROUP

\begin{tabular}{|l|l|}
\hline \multicolumn{1}{|c|}{ Aspects } & average \\
\hline Likes & 4.00 \\
\hline Understanding & 3.90 \\
\hline Display book & 3.80 \\
\hline Final Score & 3.95 \\
\hline
\end{tabular}

Based on trial results Try-Out Small Group obtained results with average to aspects like having a value of 4.00 with the criteria of "very good", in the aspect of understanding has a mean value of 3.90 with the criteria of "very good". In the aspect of interactive learning media display has an average value of 3.80 with the criteria of "very good". So the final score of the feasibility of interactive learning media worth 3.95 can say that the development of interactive learning media on subjects worthy Pancasila and Citizenship Education in the use of the test results Try-Out Small Group.

Recent tests after going through the stages of expert validation and testing of Small Group Try-Out and repair, and then be tested Field pesetas Try-out with 30 students, the results of this trial are presented in the table:

TABLE IV. TEST FIELD TRY-OUT

\begin{tabular}{|l|l|}
\hline \multicolumn{1}{|c|}{ Aspect } & \multicolumn{1}{c|}{ Average } \\
\hline love & of 3.90 \\
\hline understanding & 3,85 \\
\hline media Display & 3,92 \\
\hline Final score & 3,89 \\
\hline
\end{tabular}

Test Field trial results obtained try-outs with the average results for aspects like having a value of 3.90 with the criteria "very good", in the aspect of understanding scored 3.85 with the criteria of "very good", in the aspect of the display media obtained a value of 3.92 with the criteria of "very good". So the final score of the feasibility of interactive learning media worth 3.89 can even say that the development of interactive learning media on subjects worthy Pancasila and Citizenship Education in the use of field test results Try-Out.

Field trials Try-out is done to determine the effectiveness of instructional media Pancasila and Citizenship Education developed. Effectiveness was measured by a questionnaire to obtain feedback on the students' interactive learning media on Pancasila and Citizenship Education learning and analyzing the results of pretest and posttest learning by setting a minimum score of competency achievement of $>60$. Here are the results obtained posttest average value.
TABLE V. TEST EFFECTIVENESS ASSESSMENT

\begin{tabular}{|l|l|l|}
\hline & \multicolumn{1}{|c|}{ Pretest } & Posttest \\
\hline Minimum Value & 5.67 & $7: 00$ \\
\hline Maximum Value & $8: 50$ & 10 \\
\hline Mean & 7.08 & 8.5 \\
\hline Improvement & $1: 42$ \\
\hline
\end{tabular}

At pretest values are the average value of 7:08 after use interactive learning media on Pancasila and Citizenship Education Learning average value to 8.5 occurred an increase of 1.42. Pretest minimum value of 5.67 increased to 7:00 and a maximum value of 7:00 posttest initially rose to 10 . This shows a significant increase in the ability of students to understand the material Pancasila and Citizenship. In significance testing using two sample t-test related to the pretest and posttest shows the value of t-test $=9.01$ consulted with t-table $(\mathrm{a}=0.05: 30)$ amounted to 1.696 indicates that there are significant differences between the scores of pretest and post-test scores.

Learning using interactive learning media has an important role in improving learners' learning experiences and can train learners to think critically in solving problems and developing materials obtained by learners in accordance with Mohamed and Masood's opinion in his research "The use of integrated multimedia learning courseware is able to solve the problem of high-level thinking skills "can be interpreted the use of interactive learning media able to develop potential solutions to solve the problem of high-level thinking skills.

Based on the calculation of the t-test of the interactive learning media on Pancasila and Citizenship Education learning effectiveness is high because of the use of interactive learning media on learning Pancasila and Citizenship Education, there are a significant increase in learning outcomes. Learning activities using the help of the media can facilitate teachers to deliver learning materials so that achievement of learning goals $[6,7,8]$.

\section{CONCLUSION}

Based on the stages of research and development are passed, the conclusions of this research are as follows: Media interactive learning developed in this study proved to be valid, practical, and have a potential effect on student learning outcomes in learning Pancasila and Citizenship Education in Elementary School and Media Use learning developed interactive student can increase tolerance for material content therein is the diversity of Indonesia.

\section{REFERENCES}

[1] Sumantri, M. S., Learning Strategy Theory and Practice in Elementary Education Level.Jakarta: RajawaliPers. 2015.

[2] Pujiastuti, D., K., A., and Emosda, E,. Development-Based Learning Media MultiMedia Civics Class VIII SMP interaktifuntuk learning.Techno-pedagogyJournal,4(1). 2014.

[3] Buttenheim, A. M., and Nobies, J., Ethnic diversity, the traditional norm, and marriage. Population Studies, 277-294, 2009.

[4] A. Gouhar and Mahapatra, Interactive media and its impact on education: International Jo3urnal of Current Research. ISSN: 0975- Vol. 8, Issue, 12, pp.43964-43966, December, 2017. 
[5] Sugiyono, M. P. K., Qualitative and R \& D.Bandung: Alfabeta. 2008

[6] Dallinger, S., Jonkmann, K., Hollm, J., and Fiege, C., The effect of content and language integrated learning on students' English and history competences-Killing two birds with one stone ?.Learning andInstruction,41,23-31. 2016.
[7] Sumantri, M. S., and Rachmadtullah, R., The Effect of Learning Media and Self-Regulation to Elementary Students' History Learning Outcome.Advanced Science Letters, 22(12), 4104-4108. 2016.

[8] Arsyad, A., Learning Media. rev. ed.Jakarta: King GrafindoPersada. 2014. 